\title{
風発生装置の送風に対する“爽快感”の測定
}

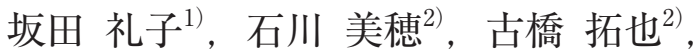 \\ 代田 光宏 ${ }^{2)}$, 松本 崇 $^{2}$, 神宮 英夫 $^{1)}$ \\ ${ }^{(1)}$ 金沢工業大学, ${ }^{2)}$ 三菱電機株式会社)
}

\section{Measurement of the Feeling of 'Invigoration' under Artificial Ventilation}

\author{
Reiko Sakata $^{1)}$, Miho Ishikawa ${ }^{2)}$, Takuya Furuhashi' ${ }^{2)}$, \\ Mitsuhiro Shirota $^{2)}$, Takashi Matsumoto ${ }^{2)}$, Hideo Jingu $^{1)}$ \\ ${ }^{1)}$ Kanazawa Institute oF Technology, ${ }^{2)}$ Mitsubishi Electric Corporation
}

\begin{abstract}
This study is designed to clarify sensation in Human Interface Systems based on sensory evaluation and measurement of physiological responses. This paper describes the measurement of the feeling of 'invigoration' under artificial ventilation. In addition, the relationship between sensory evaluation and physiological responses is investigated. (Physiological responses include facial skin temperature and sympathetic nerve activity index.) Experimental data shows that, under certain conditions, the sympathetic nerve activity index can be used as a quantitative measure of the feeling of 'invigoration' under artificial winds. As a result, under conditions that expose the whole body or the lower body to wind, the sympathetic nerve activity index corresponds with the feeling of 'invigoration' as evaluated by thermal and comfort sensory assessments. However, under conditions that expose only the upper body to wind, it is thought that negative feelings associated with wind on one's face negatively influence the sensory evaluation index. Therefore, in these situations, sensory evaluation does not correspond with the sympathetic nerve activity index.
\end{abstract}

(Received 23 June 2014, Accepted 24 July 2014)

Keywords: Thefeeling of 'Invigoration' “爽快感”, Sensory evaluation 官能評価, Physiological response 生理指標

\section{1.はじめに}

人と機械・システムの関わりにおける快適性や気持 ちよさなど，明確には意識できない，もしくは“何と なく”感じていることについて, 官能評価や生理指標 を用いてその要因を明らかにすることが本研究の目的 である。

本研究では, 風発生装置による送風の “爽快感”に 着目した，爽快とは，心理学的には活動的快であって，

著者連絡先Ｓakata.Reiko@ab.MitsubishiElectric.co.jp
爽やかな，心身の状態が良好でさっぱりして清清しい 感覚や心持ちを示す. 近年, 風発生装置は, 夏のわず かな猛暑日をしのぐための贅沢品ではなく，季節によ らず快適に暮らすための必需品となりつつあり，人工 的に生み出された送風に長時間当たることが日常的と なっている。したがって, 送風の“爽快感”に配慮し た品質が求められている.

人の身体に送風が当たると，身体の周りを覆ってい る空気の層（境界層）が吹き飛ばされて薄くなり，境 界層内外の空気が混ざり合うことで温湿度の変化が生 
じる、温湿度が低下し, それが長時間に及ぶと, 寒気 を感じて，ときには体調不良に至る場合がある。崎 ら（2006）によると，寒がりな人と暑がりな人では皮 膚温度に違いがあり，寒がりな人は，冬季に打いて皮 膚温水準が低い傾向にあるため寒さを強く感じ, 夏季 に扔いて皮膚温水準が高い傾向にあるため皮膚と環境 の温度勾配が大きいために強い冷えを感じると報告さ れている.

本報は，寒がりな人を対象とした実験により，風発 生装置の送風の“爽快感”の手掛かりを得ようとする ものである。送風について, 官能評価と生理指標との 対応を検討し, “爽快感”の要因と, その定量化の条 件を明らかにすることを目的とする。

風の官能評価に関する研究例を以下に挙げる。中村 ら（2005）は, 温湿度 $28^{\circ} \mathrm{C} 30 \%$ の環境下において, 実験室内に複数の吹出口を設け，一定時間毎に吹出口 を変える変動微風空調と一般空調機から送られる冷風 について, 脳波・心電図・皮膚電気反応の生理指標と 温冷感・快適感などの官能評価, および, クレペリン 検査用紙を用いた加算作業によって比較した．これに より, 変動微風による快適感や生産性への影響を考察 すると共に, 被験者に対する暴露風速と変動周期の組 み合わせによって, 快適と感じる風速が変わることを 報告している。また中村ら（2007）は，変動微風によ る快適性維持の効果，および，そのときの温湿度や人 の活動レベルなどの室内条件について報告している. 三宅ら（1990）は, 温湿度 $25^{\circ} \mathrm{C} 77 \%$ の環境下において,

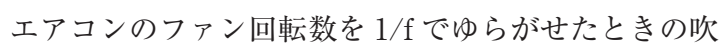
き出し風を 150 秒間曝露し, SD 法によって意味空間 を構成した。これにより，弱ゆらぎ条件と定常条件は ほぼ同じ快適性であること，拈よび，強いゆらぎ条件 が不快であり，それはファン回転による音が不快要因 になったことを報告している．

以上のことから, 風の好ましさや快適さに関わりが 深い要因として風速, および, 風速のゆらぎが考えら れる．また，風速にゆらぎをつけた製品事例もあるこ とから，本報では（ファン回転数のゆらぎによる）風 速ゆらぎ風を用いた検証によって“爽快感”の要因を 明らかにしょうと考えた。生理機能測定としては, 脳 波測定, 発汗測定, 心電測定, 皮膚温度測定が考えら れるが, その中で, 頭部に測定機器を付ける脳波測定 は, 長時間の実験においては, 機器の取り付けによる 負荷が評価結果に影響を及ぼすことが䯚念され，今回 の実験には不向きと考えた。また発汗測定は，事前に
今回の実験条件である温湿度 $28^{\circ} \mathrm{C} 50 \%$ の環境下で検 証を行ったところ, 被験者が風を意識できるほど風速 を確保すると発汗が起こらず，不向きと分かった，し たがって本報では, 官能評価と心電測定による副交感 神経活動指標掞よびサーモグラフィーによる顔面皮膚 温度を比較することとした。また，官能評価では， “爽快感” の構成要素として, 温冷感と快適感を定義 した。

\section{2. 実験方法}

寒がりな成人健常者 5 名（男 2 名, 女 3 名）を被験 者とし, 以下の方法で実験を行った。寒がりな被験者 はアンケートの自己申告で選定した.

\section{2-1. 実験環境}

室温約 $28^{\circ} \mathrm{C}$, 湿度約 $50 \%$ に設定し, 自宅リビング に扔ける安静時を想定し, 被験者に椅子座位姿勢をと らせた，身体活動強度としては，およそ1.0〜1.1Mets であった. 被験者の着衣量は半袖シャツ, ハーフパン ッ, スリッパ着用（靴下なし）とし, およそ $0.4 \mathrm{clo} の$ 夏場の薄着を再現した。

送風の条件は 6 条件であり，2 種類の風「一定風」 「ゆらぎ風」を，3種類の身体部位「顔」「胴」「全身」 に当てた。被験者は, それぞれの送風条件を 25 分間 曝露し続けた. 実験の開始前に, 被験者が室内環境に 慣れるために 5 分間の安静時間を設けた，実験は三日 に分けて行い, 一日に 2 種類の条件を実施した.

実験室は, 無風で温湿度の管理が可能な部屋であり, 大きさは抢よそ幅 $4 \mathrm{~m} \times$ 奥行き $8 \mathrm{~m} \times$ 高さ $3 \mathrm{~m}$ であっ た. 被験者は前後左右の壁面から $2 \mathrm{~m}$ 以上離れた位置 に座ってもらった，これは, 実験室の大きさとエアコ ン設置可能位置の制約の中で, 被験者と壁面との距離 をできるだけ長くしたものである.エアコンは高さ $2 \mathrm{~m}$ に設置し, 被験者の顔面はエアコンから $2 \mathrm{~m}$ 離れ た位置となるようにした。詳細は Fig. 1 に示す.

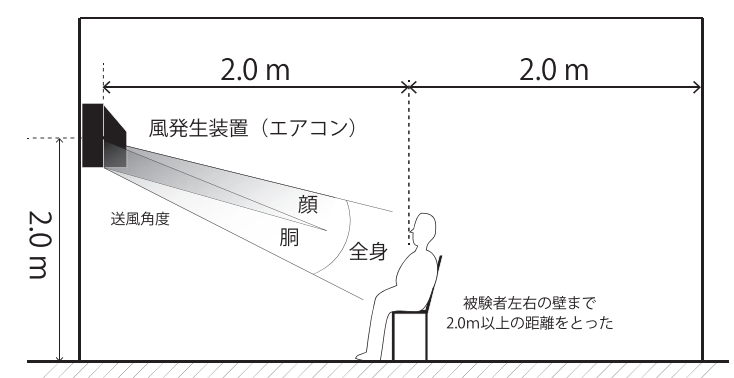

Fig. 1 実験環境 
また，実験計画にあたって，人間工学会の「人間工 学研究のための倫理指針」を参考に, 遵守すべき原則 を守るように実験内容を決めた。倫理問題に関して, 実験内容を金沢工業大学拈よび三菱電機（株）の複数 の関係者からの了解を得ており, 被験者に対しては, 事前に実験内容の説明を行い, 体調の不良を少しでも 感じたら中断することを伝え, 実験参加の同意を得て 実施した。

\section{2-2. 風の特性}

風発生装置はエアコン（三菱電機製 MSZ-ZW223, および，ファン回転数変更品）を送風モードで使用し， ファン回転数にゆらぎを付与した吹き出し風（ゆらぎ 風）と, ゆらぎを付与しない吹き出し風（一定風）の 二種類の風を用いた。ゆらぎ風と一定風の物理的な特 性として, 全身に向けて風を当てた時の被験者胸元位 置での風速を, 風速計（株式会社ソニック製 WA790）を用いて測定し, ゆらぎ風は 25 分間の平均風速 $0.29 \pm 0.23 \mathrm{~m} / \mathrm{s}$, 一定風は 25 分間の平均風速 $0.30 \pm$ $0.12 \mathrm{~m} / \mathrm{s}$ とした。両者は, 風速の偏差（風速変動） には差があるものの, 平均風速はほぼ同じである。一 定風とゆらぎ風の二種類の風は同様の形状のエアコン から吹き出すものであり, 被験者がエアコンを見ただ けで送風の種類を判断することは出来ないようにした. 送風を身体部位「顔」「胴」「全身」の三力所に当てる ため, 風の方向を吹出口のルーバー角度及び開口度で 調整した.

\section{2-3. 評価方法}

\section{（1）官能評価}

“爽快感” の構成要素として, 温冷感と快適感とを 定義した.

温冷感の評価尺度は 7 段階評価 $(+3$ 暑い, +2 暖 かい, +1 やや暖かい，0 どちらともいえない, -1 やや涼しい, -2 涼しい, -3 寒い) とした。“爽快 感”に対しては， 0 点が最も評価が高く, 評点が上下 にかい離するほど, 評価が低いものと想定される.

快適感の評価尺度も 7 段階評価（+3 とても快適で ある, +2 快適である, +1 やや快適である, 0 どち らともいえない, -1 やや不快である, -2 不快であ る，-3とても不快である）とした，これは “爽快感” に対して直接的な評価であり, 評点が高いほど評価が 高いと想定される.

風を当て始めてから 2 分毎に計 12 回, 評点をつけ てもらった。

（2）副交感神経活動指標
心電計（株式会社マイクロ・メディカル・デバイス 製 RF-ECG）を使用して $204 \mathrm{~Hz}$ で測定し, Bonaly Light（諏訪卜ラスト社）を用いて LF 成分領域 (0.04 $\sim 0.15 \mathrm{~Hz})$, HF 成分領域 $(0.15 \sim 0.40 \mathrm{~Hz})$ を 2 秒間隔 で計算した。これにより副交感神経の活動指標として, $\mathrm{HF} /(\mathrm{LF}+\mathrm{HF})$ を求めた。 この測定手法は, 著者ら が既往研究（2013）で用いたものと同一である. 風あ て開始前の安静時間（5 分間）の副交感神経活動指標 を求めて基準とし, 基準から值が高い場合はリラック ス状態, 值が低い場合はストレス状態とした.

自宅リビングに打ける安静時の設定であるため, リ ラックス状態の指標值が高いほど, “爽快感”が得ら れていると想定する.

\section{（3）顔面皮膚温度}

サーモグラフィー（NECAVIO 製 Thermo Shot F30）による体表面皮膚温度の測定を行い, 顔面皮膚 温度を 2 24 分の 2 分毎に計 12 回取得した. 顔面皮 虞温度の最高温度と平均温度の数值, 温度分布の画像 を得た。

\section{3. 結果および考察}

\section{3-1. 顔面皮膚温度}

Fig. 2 に, 送風 6 条件について 2 分毎の最高表面温 度の平均と標準偏差 $($ Mean $\pm \mathrm{SD})$ で示す.

風当ての各部位ごとに一定風とゆらぎ風とを比較す ると, いずれの部位でも統計的な有意差がみられな かった. 2 分毎の温度分布画像を目視で確認しても顕 著な違いはなかった。この理由は, 二種類の送風は風 速変動に違いがあるものの平均風速がほぼ同じであっ たため, 体表面皮膚温度では顕著な差が得られなかっ たと考えられる．また部位としては，顔に風を当てる 条件に扔いて若干温度が低いものの, 統計上の有意差 はなかった。したがって, 顔面皮膚温度は本研究にお ける “爽快感”の指標とはなり得ないことが分かった。

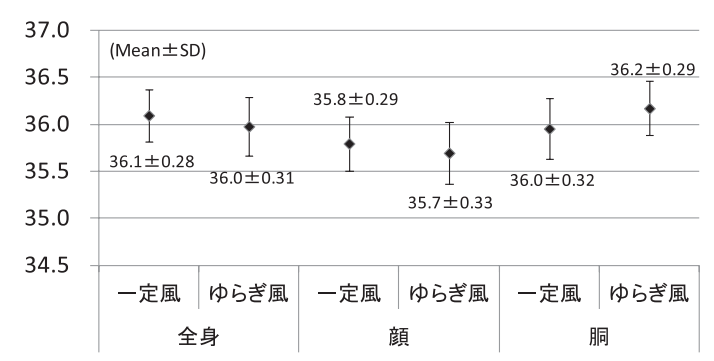

Fig. 2 顔面皮膚温度 


\section{3-2. 官能評価と自律神経活動指標}

送風の 6 条件ごとに官能評価の温冷感, 快適感と自 律神経活動指標の時間変化の傾向を解析した. 解析は, 風を当てた一連の実験の経時データに対して, 測定時 点間の相関を考慮して, 時間変化が平行的であるかど うかを明らかにするため, プロファイル分析を用いた. プロファイル分析によって, 官能評価と生理指標の経 時データについて, 一定風とゆらぎ風の二種類の送風 で時間変化が平行的であるかどうかを明らかにするた め, 平行性と平行幅の検定を実施した。プロファイル 分析が平行的であるということは，送風の種類と測定 時点との間に交互作用が無いことを意味している（藤 越, 2008). 解析対象のデー夕は, 風曝露による人体 への影響のうち, 突発的な変化ではなく, 25 分間の 傾向をみるために, 始め (2〜8 分), 中間 (10〜16 分), 後半（18〜24 分）と分けた. プロファイル分析のグ ラフは, 平均士標準偏差 $(\mathrm{Mean} \pm \mathrm{SD})$ で示した.

\section{3-2-1. 全身（上半身と下半身）に風を当てた条件}

\section{（1）温冷感}

Fig. 3 に温冷感の結果を示す。一定風とゆらぎ風は どちらも経過時間に伴い涼しい領域に移行する傾向で あり，平行となった $(F(1,16)=0.37, n . s$.$) . 一定風は$ やや涼しいから涼しいの範囲で推移したのに対して, ゆらぎ風は評点 0 前後で推移しており, 平行幅に $1 \%$ 水準以下の有意な幅の違いがみられた $(F(1,16)=$ $22.9, p<0.01)$. この結果より全身に風を当てた場合は, ゆらぎ風の方が，一定風よりも“爽快感”の評価が高 かった.

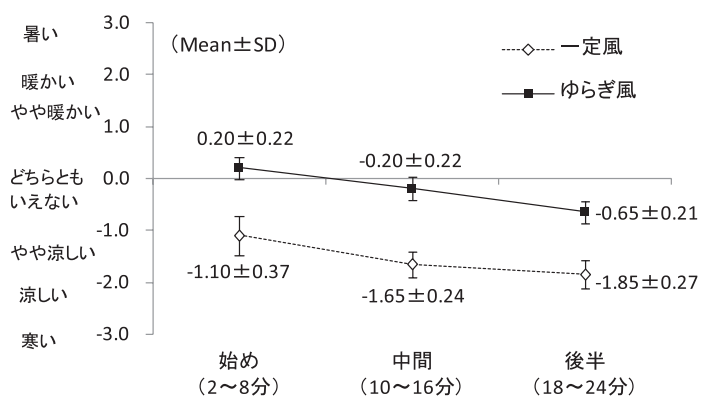

Fig. 3 全身風当て時の温冷感の推移

\section{（2）快適感}

Fig. 4 に快適感の結果を示す。一定風とゆらぎ風は, どちらも経過時間に伴い評点が低くなる傾向であり, 平行となった $(F(1,16)=1.82, n . s$.$) . 一定風は評点 0$ 前後で推移したのに対して,ゆらぎ風は快適からやや
快適の範囲で推移しており, 平行幅に有意な差がみら れた $(F(1,16)=4.35, p<0.05)$.この結果からも, 全 身に風を当てた場合は，ゆらぎ風の方が，一定風より も“爽快感”の評価が高かった，被験者の内省報告で, 全身にゆらぎ風を当てた条件は自然風のようだった， というコメントも得られている。 しかし，いずれにし ても時間経過に伴い, “爽快感” は減少する傾向で あった。

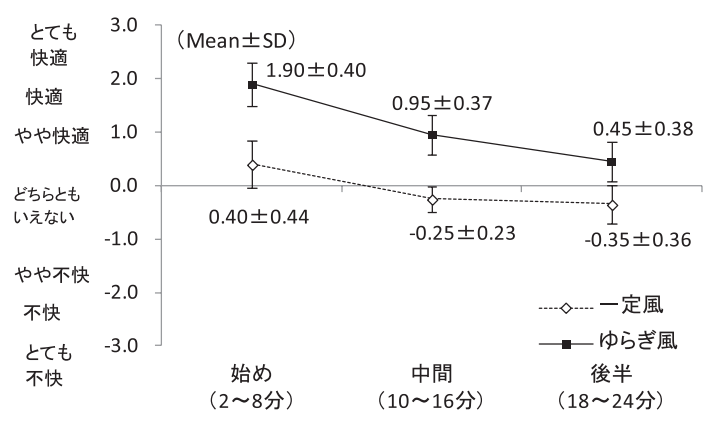

Fig. 4 全身風当て時の快適感の推移

\section{（3）副交感神経活動指標}

Fig. 5 に副交感神経活動指標の結果を示す.ゆらぎ 風は全時間帯でリラックス状態となり, 右肩下がりの 官能評価と同一の傾向を示したのに対して, 一定風は 安静時平均值近傍でやや右肩上がりの横ばいの傾向と なった，時間変化の傾向は平行となり $(F(1,16)=0.54$, $n$. s. ) , 平行幅は $1 \%$ 水準以下の有意差がみられた $(F$ $(1,16)=81.0, p<0.01)$. この結果から, ゆらぎ風に対 しては, 副交感神経活動指標は, 官能評価の“爽快 感”に対応する指標となり得ることが分かった。一方， 一定風に対しては, 官能評価の評点が元々低いことも あり，傾向が一致していなかった。

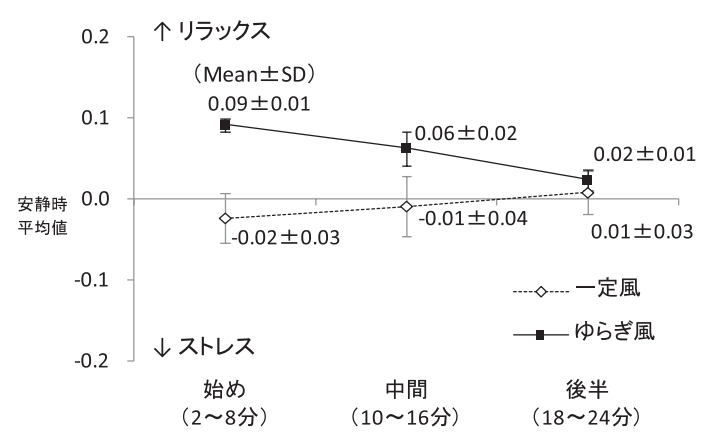

Fig. 5 全身風当て時の副交感神経活動指標の推移 


\section{3-2-2. 胴（下半身周辺）に風を当てた条件}

\section{(1) 温冷感}

Fig. 6 に温冷感の結果を示す．いずれの風も全時間 帯で涼しく感じられており, 平行性には差がなかった $(F(1,16)=0.50, n . s$.$) . いずれの風も涼しいと感じら$ れていたが，ゆらぎ風の方がその傾向が顕著であり， 平行幅に有意傾向がみられた $(F(1,16)=2.76, p<0.10)$. この理由として，今回の実験環境では着衣がハーフパ ンッとスリッパ着用（靴下なし）なので, 胴部分に送 風した風が下脚部や足部にも当たっていたため冷えを 感じやすかったと考えられる，その中で風速変動の多 いゆらぎ風は, 突発的に起こる強い風速があることで, 一定風よりも涼しく感じる度合いを強めている.

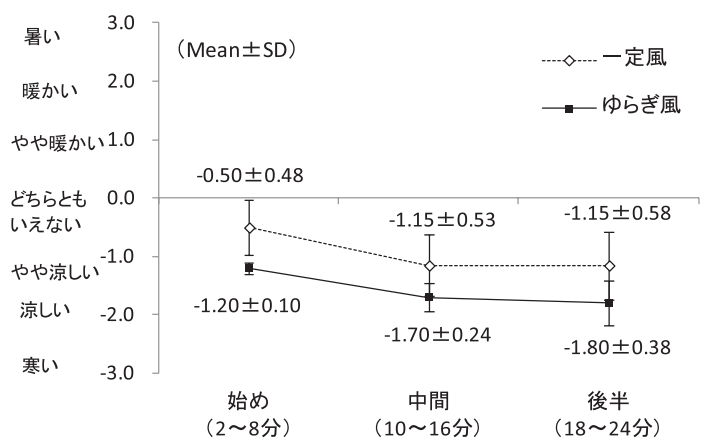

Fig. 6 胴に風当て時の温冷感の推移

\section{（2）快適感}

Fig. 7 に快適感の結果を示す.いずれの風も評点 0 前後ではあるが右肩下がりで推移し，平行性拉よび平 行幅に差がみられなかった $(F(1,16)=0.73, n . s ; F$ $(1,16)=1.40, n . s$.$) . この結果から，胴に風をあてる$ と, Fig. 6 のように涼しく感じるものの, それが不快 感につながるわけではなかった。しかしながら，“爽 快感”としての評価は低かった。

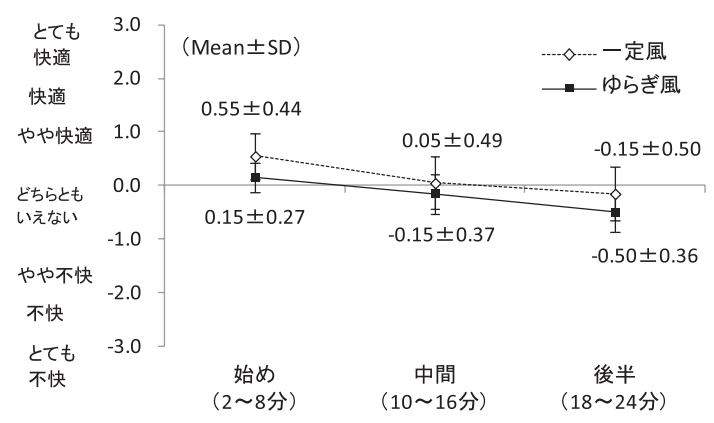

Fig. 7 胴に風当て時の快適感の推移

\section{（3）副交感神経活動指標}

Fig. 8 に副交感神経活動指標の結果を示す.いず れの風も被験者ごとのばらつきが大きいものの，時間 変化は右肩下がりの傾向となり, 平行性には差がみら れなかった $(F(1,16)=1.07, n . s$.$) . いずれの風も安静$ 時よりもほぼストレス状態の範囲で推移したが，ゆら ぎ風の方がその傾向が顕著であり, 平行幅に有意差が みられた $(F(1,16)=6.85, p<0.05)$ 。この結果から, 胴および下半身に風をあてることは，風の種類に関わ らず副交感神経活動指標はストレス状態となった。そ の中で，ゆらぎ風に対してはストレス状態の度合いが 強く, Fig. 6 の涼しく感じる度合を反映しているもの と考えられる。

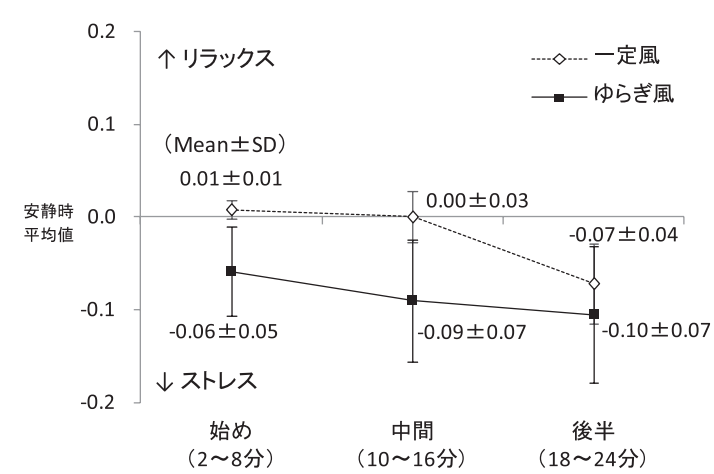

Fig. 8 胴に風当て時の副交感神経活動指標の推移

\section{3-2-3. 顔（上半身周辺）に風を当てた条件 （1）温冷感}

Fig. 9 に温冷感の結果を示す.一定風は経過時間に 伴い涼しく感じられるのに対して, ゆらぎ風は時間帯 によって評価が増減し, 平行性には有意な差がみられ た $(F(1,16)=5.42, p<0.05)$. 平行幅は差がみられな かった $(F(1,16)=3.55, n . s$.$) . いずれの風も，やや涼$ しいから涼しいの領域で推移しており, 顔も涼しさを 感じやすいことが分かった。ゆらぎ風のほうが涼しく 感じる度合が強いのは, 胴に風を当てた場合と同様で ある。

\section{（2）快適感}

Fig. 10 に快適感の結果を示す。一定風もゆらぎ風 も経過時間に伴い右肩下がりであるが，ゆらぎ風は始 めの時間帯からやや不快と評価され，平行性には有意 な差がみられた $(F(1,16)=5.57, p<0.05)$ ．平行幅に は差はみられなかった $(F(1,16)=2.23, n . s$.$) .この結$ 果は, Fig. 9 の温冷感の傾向と類似しており, 顔に風 


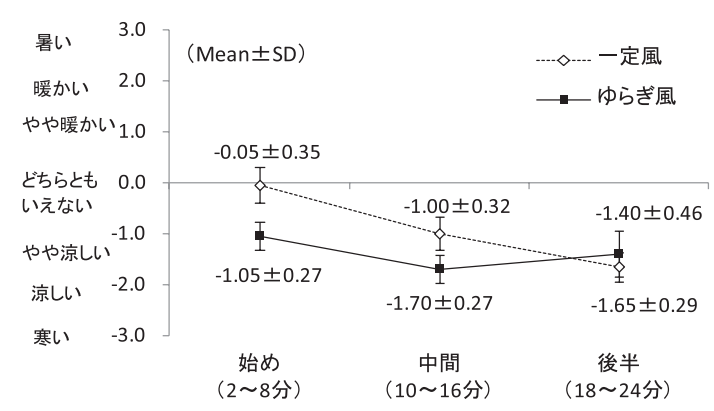

Fig. 9 顔に風当て時の温冷感の推移

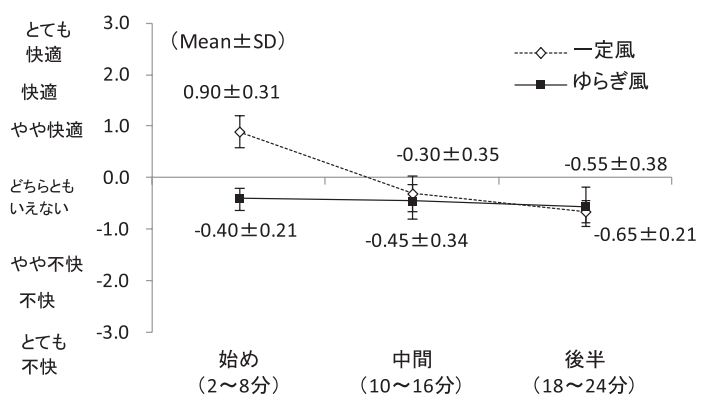

Fig. 10 顔に風当て時の快適感の推移

を当てる場合の “爽快感” の評価は低い。被験者の内 省報告で，顔にゆらぎ風を当てた条件は（風速が）強 い風が顔にあたるときに嫌悪感があっていやだった， というコメントも得られている.

\section{（3）副交感神経活動指標}

Fig. 11 に副交感神経活動指標の結果を示す。いず れの風もほぼ横ばいの傾向となり平行性に差はなかっ た $(F(1,16)=0.29, n . s$.$) . ゆらぎ風はリラックス状態$ で推移するのに対して, 一定風はストレス状態で推移

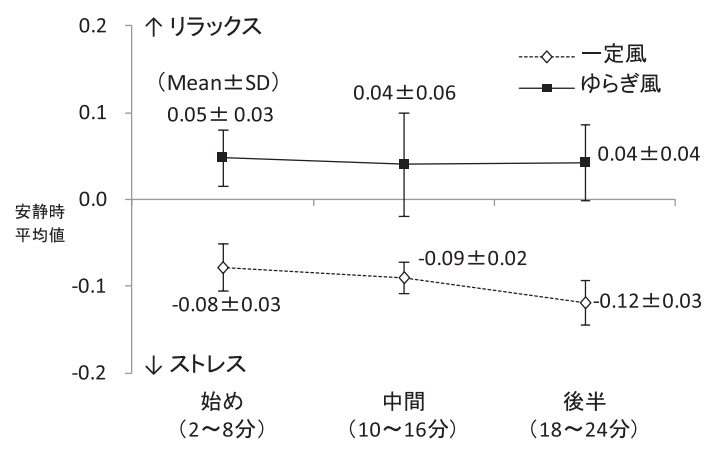

Fig. 11 顔に風当て時の副交感神経活動指標の推移
し，平行幅には有意な差がみられた $(F(1,16)=9.92$, $p<0.05)$.

顔に一定風をあてる条件は，官能評価の評点の低さ を反映して，副交感神経活動指標がストレス状態を示 しているが，ゆらぎ風をあてる条件では，副交感神経 活動指標がリラックス状態を保っており, 結果が対応 していなかった.

\section{4. まとめ}

全身（上半身と下半身）にゆらぎ風を当てた条件で は, 時間経過に伴い, 官能評価の温冷感が 0 点近傍で 推移し（Fig. 3), 快適感が快適からやや快適の領域 で右肩下がりの傾向を示す（Fig. 4）のに対応して, 副交感神経活動指標がリラックス状態の領域内で右肩 下がりの同一傾向を示しており（Fig. 5)，温冷感と 快適感で評価する “爽快感” の定量指標となり得るこ とが分かった.

また, 胴（下半身周辺）にゆらぎ風を当てた条件で も, 官能評価の快適感が 0 点近傍で推移し (Fig. 7), 温冷感がやや涼しいから涼しい領域で右肩下がりの傾 向を示す（Fig. 6）のに対応して, 副交感神経活動指 標がストレス状態の領域内でほぼ同一傾向で推移して おり（Fig. 8), 温冷感と快適感で評価する “爽快感” の定量指標となり得ることが分かった。

一方で, 顔 (上半身周辺) にゆらぎ風を当てた条件 では，官能評価の温冷感はやや涼しいから涼しい領域 で推移し（Fig. 9), 快適感がやや不快の領域で推移 している（Fig. 10）にも拘わらず，副交感神経活動 指標がリラックス状態の領域内で推移しており（Fig. 11 実線)，一致していなかった。一定風を顔に当て る場合の副交感神経活動指標がストレス状態の領域内 で推移している（Fig. 11 破線）のと対照的である. 顔のように外的刺激に敏感な部位に風を当てる場合の “爽快感”については, 官能評価の指標に顔に風が当 たることの嫌悪感のような顕在的な意識が影響しやす く, 潜在的な生理指標とは対応しない可能性が考えら れる。

\section{5. おわりに}

本報は，寒がりな人を被験者として，風発生装置の 送風の“爽快感”について検討した。

送風の種類（一定風, ゆらぎ風）と風当て部位（全 身, 顔, 胴）の条件ごとに, 主観による官能評価（温 冷感, 快適感) と顔面皮膚温度, 副交感神経活動指標 
を比較し, 客観的な定量指標の可能性を探った。結果 として, 顔面皮膚温度は, いずれの送風条件でも顕著 な差がなく, 定量指標となり得ないことが分かった。 副交感神経活動指標は, 条件によっては, 今回の温冷 感と快適感で評価する “爽快感” の定量指標となり得 ることが分かったが，顔にゆらぎ風を当てる場合は， 想定する結果と一致しなかった。

また風発生装置の送風モードにおける機能・品質の 観点からは以下のことが分かった.

・全身に風を当てる場合は, ゆらぎ風の方が, 一定風 よりも官能評価で良い結果となり, 副交感神経活動 指標もそれを裏づける結果となった。

・室温が約 $28^{\circ} \mathrm{C}$ と八の体温よりやや低めの場合, 寒 がりの人に対しては, 今回の風速を一定時間以上維 持することは好ましくない.

- 風発生装置の機能として, 風を当てる身体部位, ファン回転数によるゆらぎの付与を検討するととも に, 時間経過に伴う平均風速の変化も考慮する必要 性が示唆された。なお，風を当てる身体部位につい ては, 夏場の薄着を想定した着衣で胴部位に集中的 に送風することは好ましくないと考えられた．

\section{参考文献}

藤越康祝, 菅民郎, 土方裕子 (2008), 経時データ分 析, オーム社開発局編, 株式会社オーム社, 東京, pp. $71-81$.

三宅晋司, 鎌田豊彦, 神代雅春（1990）Comfortableness or Fluctuating Air Flow : Subjective Assessment of the Air Flow of an Air-conditioner with 1/f Fluctuating Fan Speed, 産業医科大学雑誌, 12 (3), pp. 323-333.

中村弘和, 中山和美, 射場本忠彦, 時津晴司 (2005) 変動微風空調システム実用化に関する研究（第 1 報）変動微風が快適性およびプロダクティビティに 与える影響の把握, 空気調和・衛生工学会大会学術 講演論文集, pp. 853-856.

中村弘和, 射場本忠彦, 時津晴司 (2007) 変動微風空 調システムの実用化に関する研究－変動微風が心理 量および生理量に与える影響一, 日本建築学会環境 系論文集, 618, pp. 23-30.

坂田礼子, 神宮英夫（2013）生理計測を用いた感性の 定量評価技術に関する研究-機器操作時のサクサク 感について-, 日本感性工学会論文誌, 13 (1), pp. 49-54.

山崎和彦, 野尻佳代子, 佐藤庸子, 石橋圭太, 樋口重 和, 前田亭史 (2006) 日本人成人の体温調節反応に おける性，季節および暑がりと寒がりの影響，日本 生理人類学会誌, 11 (1), pp. 21-28. 